THE COPERNICAN QUESTION 
This page intentionally left blank 


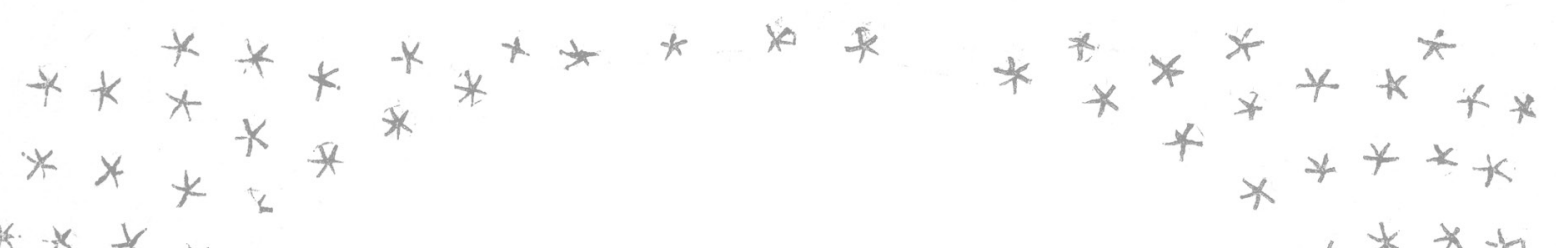

$$
\begin{aligned}
& \text { *** * * } \\
& \text { 火* } * \\
& * * \\
& * * \\
& \text { ***十 } \\
& \text { * } k \text { * } \\
& x-x \\
& *
\end{aligned}
$$

\section{THE COPERNICAN QUESTION}

Robert S. Westman

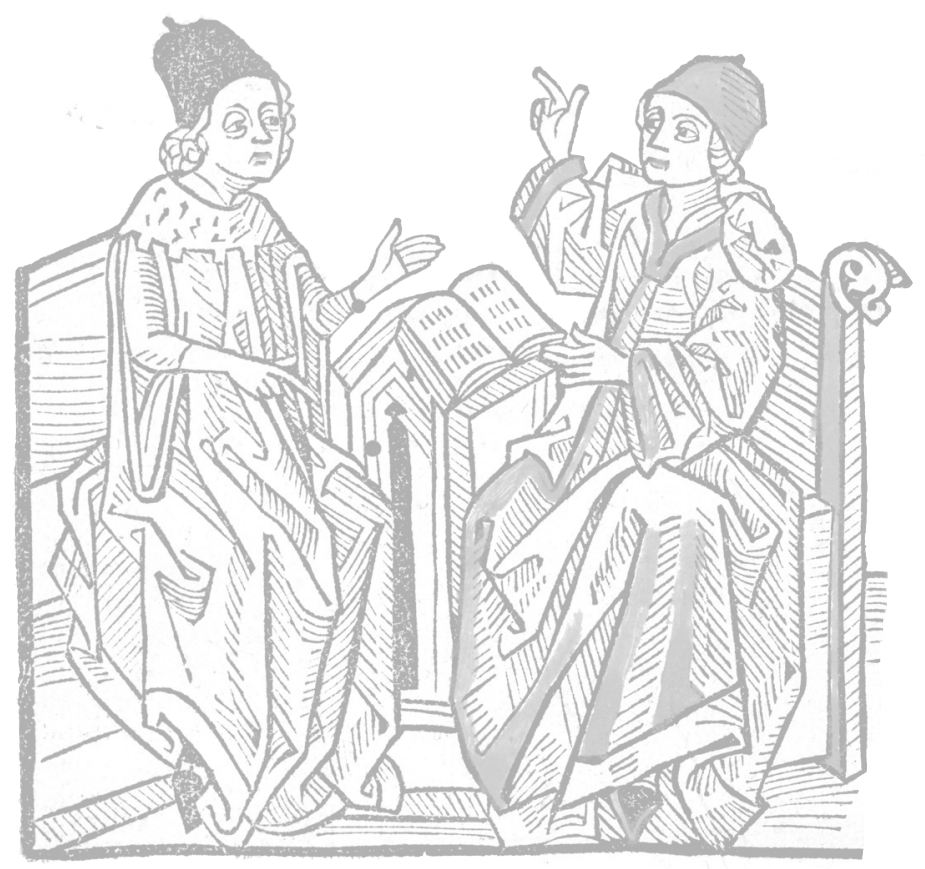

UNIVERSITY OF CALIFORNIA PRESS

Berkeley Los Angeles London 
University of California Press, one of the most distinguished university presses in the United States, enriches lives around the world by advancing scholarship in the humanities, social sciences, and natural sciences. Its activities are supported by the UC Press Foundation and by philanthropic contributions from individuals and institutions. For more information, visit www.ucpress.edu.

University of California Press

Berkeley and Los Angeles, California

University of California Press, Ltd.

London, England

(C) 2011 by The Regents of the University of California

Library of Congress Cataloging-in-Publication Data

Westman, Robert S.

The Copernican question : prognostication, skepticism, and celestial order / Robert S. Westman.

p. $\mathrm{cm}$.

Includes bibliographical references and index.

Is B N 978-0-520-25481-7 (cloth : alk. paper)

1. Astronomy, Renaissance-Europe-History-16th century.

2. Science-Philosophy-Europe-History-16th century.

3. Copernicus, Nicolaus, 1473-1543. 4. Galilei, Galileo, 1564-

1642. 5. Kepler, Johannes, 1571-1630. I. Title.

QB29.W47 2011

$520.94^{\prime} 09031-\mathrm{dc} 22$

2009039562

Manufactured in the United States of America

$\begin{array}{llllllllll}20 & 19 & 18 & 17 & 16 & 15 & 14 & 13 & 12 & 11\end{array}$

$\begin{array}{llllllllll}10 & 9 & 8 & 7 & 6 & 5 & 4 & 3 & 2 & 1\end{array}$

In keeping with a commitment to support environmentally responsible and sustainable printing practices, UC Press has printed this book on Rolland Enviro100, a 100\% post-consumer fiber paper that is FSC certified, deinked, processed chlorine-free, and manufactured with renewable biogas energy. It is acid-free and EcoLogo certified. 
For my wife, Rachel, my sons Aaron and Jonathan, and to the memory of my brother, Walt 
How many people [who] are immersed in a discipline are used to reducing everything to it, and not because of a desire to explain everything by it, but because things really seem like that to them. What happens to them is like someone who walks immersed in snow and to whom everything ends up appearing white ... like someone who loves in vain and sees the face of his beloved in everything. ... So he who is a theologian, and nothing but a theologian, takes everything back to divine causes; he who is a doctor takes everything back to corporal states, the physicist to the natural principles of things, the mathematician, like the Pythagoreans, to numbers and figures. In the same way, the Chaldeans were entirely occupied with the measurement of celestial movements and the observation of the positions of the stars ... and all things were stars to them, and they willingly took everything back to the stars.

GIOVANNI PICO DELLA MIRANDOLA, Disputationes contra Astrologiam Divinatricem, 1496

TEOFILO: Coming back to Nundinio, at this point he started to show his teeth, gape his jaws, squint his eyes, wrinkle his eyebrows, flare his nostrils and utter a capon's crow from his windpipe, in order to make the people present understand by that laughter that he understood well, that he was right while the other was saying ridiculous things.

FRULLA: Is not the truth of what the Nolan said proven by the fact that Nundinio laughed at it so much?

GIORDANO BRUNO, La cena de le ceneri, 1584

I see some who study and comment on their almanacs and cite their authority in current events. With all they say, they necessarily tell both truth and falsehood. For who is there who, shooting all day, will not sometime hit the mark? [Cicero] ... Besides, no one keeps a record of their mistakes, inasmuch as these are ordinary and numberless; and their correct divinations are made much of because they are rare, incredible, and prodigious.

MiChel de montaigne, "Of Prognostications," in Essays, 1580

It's tough to make predictions, especially about the future.

Attributed to YOGI BERRA

(and, in a slightly different version, to Niels Bohr)

The only function of economic forecasting is to make astrology look respectable. JOHN KENNETH GALBRAITH 